\title{
PERMANENT FLACCID PARAPLEGIA IN CHILDREN WITH THORACIC SPINAL CORD INJURY*
}

\author{
By E. Boltshauser, M.D., W. Isler, M.D., H. U. BuCher, M.D. and \\ H. FRIDERICH, M.D. \\ Children's University Hospital, Steinwiesstrasse 75, 8032 Zürich, Switzerland
}

\begin{abstract}
Among 12 children with complete thoracic spinal cord injury four developed permanent flaccid paraplegia with areflexia and an autonomous bladder. Clinical, neurophysiological and myelographic findings favour an extensive lower motor neurone lesion (myelomalacia).
\end{abstract}

Key words: Spinal cord injury; Spinal cord infarction; Flaccid paraplegia; Myelography; Nerve conduction velocity.

\section{Introduction}

IN the acute phase of traumatic spinal cord injury flaccid paraplegia and areflexia are constant features. Once the stage of spinal shock subsides there is reflex return and some degree of hyperreflexia and spasticity evolves. This applies to trauma to the thoracic cord while it is well recognised that lesions of the lumbosacral cord and cauda equina commonly result in flaccid paraplegia. Failure of reflex return in thoracic lesions is unusual and destruction of grey matter in the vertical plane seems to be prerequisite (Guttmann, I973).

When we reviewed a series of children who sustained spinal cord injuries we were surprised to find four cases with permanent flaccid paraplegia following thoracic cord trauma. These cases are the topic of this report.

\section{Patients}

\section{Material and Methods}

From January I960 to March 197925 children with spinal cord trauma were admitted to our hospital. Details with particular reference to long-term rehabilitation have been reported elsewhere (Bucher et al., 1980). The age at injury was below I 2 years, apart from two patients ( 13 years and I6 years respectively). The transverse lesions were incomplete in nine and complete in I4 children, while two cases were lost to follow-up. There were I 2 complete lesions with a neurological level above Ti2 segment. In the period under review Io newborns with birth injury to the spinal cord were seen. They have been described separately (Bucher et al., 1979) and will not be discussed further.

\section{Nerve conduction velocity (NCV)}

Using DISA equipment NCV measurements were obtained in the median nerve. Measurements in the lower limbs were attempted in both tibial and peroneal nerves using surface stimulating electrodes and needle recording electrodes. Registration of H-reflex was tried by stimulation of the tibial nerve in the poplitea and recording over the $\mathrm{m}$. triceps surae.

\footnotetext{
* Dedicated to Prof. A. Prader on the occasion of his 6oth birthday.
} 
Myelography

Lumbar myelography, using metrizamide (Amipaque), was performed in two children (cases I and 2) without local or general anaesthesia. There were no adverse side-effects. The air myelogram shown for comparison in Fig. 3 was performed under general anaesthesia.

\section{Description of Cases}

Table I summarises some relevant data of our four cases with permanent flaccid paraplegia. Before further details are added below, a description of findings common to all patients follows.

TABLE I

\begin{tabular}{|c|c|c|c|c|c|c|c|}
\hline \multirow{2}{*}{\multicolumn{2}{|c|}{ Case/Sex }} & \multicolumn{2}{|c|}{ Age (years) } & \multirow{2}{*}{$\begin{array}{l}\text { Neurol. segment } \\
\text { of cord lesion }\end{array}$} & \multirow{2}{*}{ Ambulation } & \multirow{2}{*}{ Last IVP } & \multirow{2}{*}{ Other remarks } \\
\hline & & At injury & At present & & & & \\
\hline I & $\mathrm{f}$ & $I_{2}^{\frac{1}{2}}$ & 5 & $\mathrm{~T}_{7}$ & Rollator & $\begin{array}{l}\text { I978 (July) } \\
\text { normal }\end{array}$ & $\begin{array}{l}\text { Neurofibromatosis } \\
\text { Glioma optic chiasm }\end{array}$ \\
\hline 2 & $\mathrm{~m}$ & $9 \frac{3}{4}$ & I4 & $\mathrm{T}_{7}$ & $\underset{\text { gait }}{\text { Swing-through }}$ & I979 (July) & Myelography-Fig. 2 \\
\hline 3 & $\mathrm{~m}$ & $5 \frac{1}{2}$ & I $8 \frac{1}{2}$ & $\mathrm{~T}_{9}$ & $\begin{array}{l}\text { Swing-through } \\
\text { gait } \\
\text { Drives car }\end{array}$ & $\begin{array}{l}\text { norma } \\
\text { nor6 } \\
\text { normal }\end{array}$ & Marked scoliosis \\
\hline 4 & $\mathrm{~m}$ & I I $\frac{1}{4}$ & 25 & $\mathrm{~T} 8$ & $\begin{array}{l}\text { Wheel-chair } \\
\text { Drives car }\end{array}$ & $\begin{array}{l}\text { I979 (July) } \\
\text { Mild hydro- } \\
\text { nephrosis }\end{array}$ & $\begin{array}{l}\text { Marked scoliosis } \\
\text { Diabetes mellitus }\end{array}$ \\
\hline
\end{tabular}

\section{General remarks}

All cases sustained comparatively minor trauma to the spine. While the accident in case I led immediately to a complete paraplegia, the neurological deficit resulting in complete transverse lesions evolved within half an hour in cases 2 and 4, and was realised only some hours later in case 3. Radiographs revealed no bone injuries. The transverse lesions remained complete and there was no sacral sparing of sensation. The lower limbs remained completely flaccid with muscular wasting, absence of tendon reflexes and complete sensory loss. Abdominal, anal (and in males cremasteric) reflexes were abolished. Plantar stimulation brought no response. There were no foot deformities but cases 3 and 4 have considerable scoliosis. There were no para-articular ossifications.

Case I. This $I \frac{1}{2}$ year-old girl was thrown out of her push-chair which was hit by a car. She had immediate complete paraplegia with a sensory level at the lower costal margin. Myelography was normal and CSF was clear. Her neurological condition did not change subsequently and she remained flaccid and areflexic in her legs. So far she has had four fractures of her lower legs due to osteoporosis. She had recurrent urinary tract infections but intravenous pyelography was completely normal (August 1978). Bladder rehabilitation with regular suprapubic tapping was not successful and her bladder has to be emptied by gentle manual pressure.

Already on her first admission multiple large café-au-lait spots were recognised and neurofibromatosis was considered. At the age of $4 \frac{1}{2}$ years strabismus was noted. There was bilateral optic atrophy. An optic chiasm glioma was suspected and confirmed by computed tomography. Myelography was performed at $4 \frac{3}{4}$ years (Fig. I). 
a
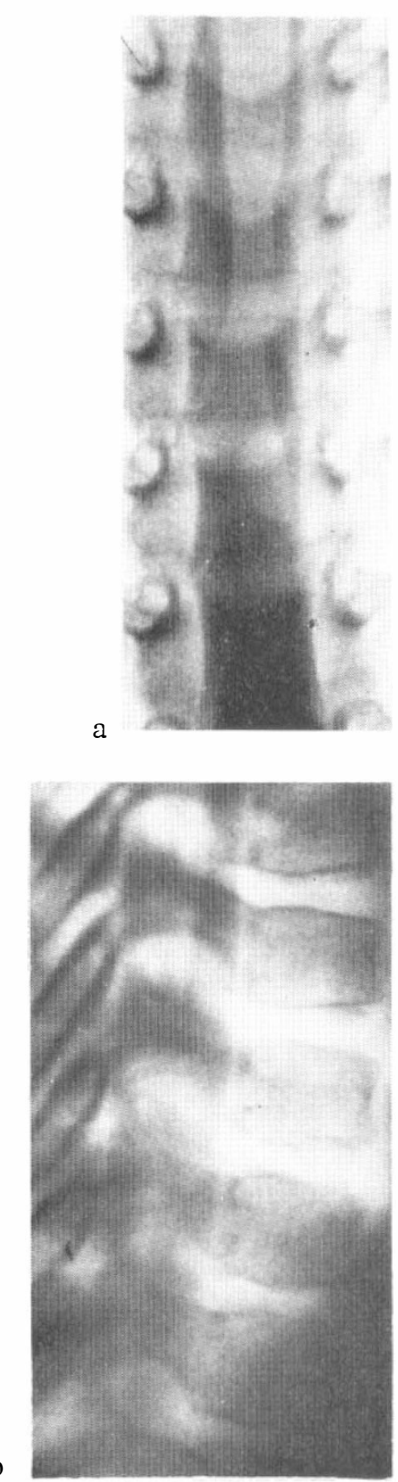
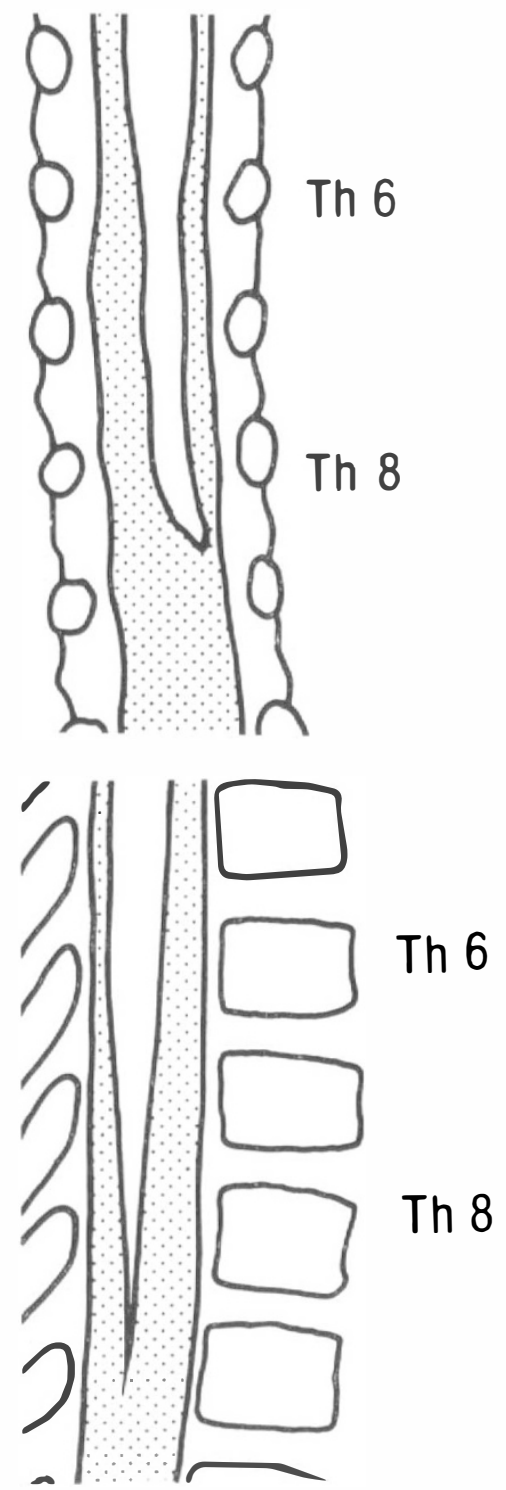

FIG. I

Case I. Complete lesion corresponding to $\mathrm{T}_{7}$ segment. Metrizamide myelography, A.P. view (Fig. Ia): Irregular contour of spinal cord in mid-thoracic region. Cord not clearly visualised below T8 vertebra. Lateral view (Fig. Ib): The spinal cord tapers to a point at T8/9 vertebral level.

Case 2. This $9 \frac{3}{4}$-year-old boy fell from a van on his buttocks. He experienced marked backache but he managed to get up and walk a few steps before he collapsed because of weakness of his legs. Details of his initial neurological examination are not known but he was subsequently found to have persistent complete flaccid paraplegia corresponding $\mathrm{T}_{7}$ segment. Rehabilitation was successful in so far as he reached complete independence. $\mathrm{He}$ is able to walk long distances by swing-through gait. He had no ulcers, no fractures, no urinary tract infections and he has only mild scoliosis. However he did not develop an 

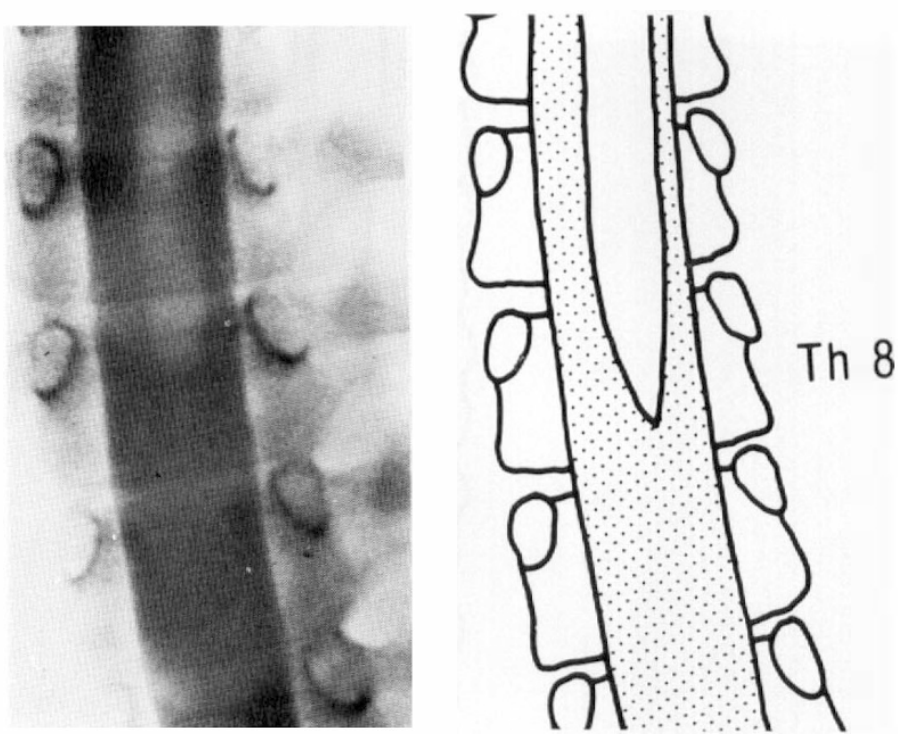

Fig. 2

Case 2. Complete lesion corresponding to $\mathrm{T}_{7}$ segment. Metrizamide myelography, A.P. view: Cone-shaped spinal cord at T8 vertebral level, not recognised below this point.

automatic bladder and he only voids following suprapubic tapping by gentle manual pressure. He had a normal intravenous pyelogram in July 1979. Myelography was performed at $14 \frac{1}{2}$ years (Fig. 2).

Case 3. This patient was said to have fallen out of his bed at night when he was $5 \frac{1}{2}$ years old. He complained immediately of pain and weakness in his lower limbs. The following morning he woke up paraplegic and incontinent. CSF examination revealed clear fluid. He had a permanent complete cord lesion with flaccidity and areflexia corresponding to a level of T9. He gained complete independence, and walks up to $10 \mathrm{~km}$ by a swingthrough gait; he has no wheel-chair and he drives a car. There have been several skin ulcers and three fractures due to falls. He has not had any urinary tract infection, but he failed to develop an automatic bladder and voids with abdominal pressure. The last IVP (1976) was normal. He refused a repeat IVP and urodynamic studies.

Case 4. This patient has had diabetes mellitus since he was aged 3 years. At the age of I I during gymnastics he fell onto his back from a height of about $\mathrm{I} \frac{1}{2}$ metres, had intense pain and experienced some weakness of his lower limbs. Within half an hour he had complete paraplegia. On admission the CSF was normal as was myelography. A repeated myelogram 6 weeks later showed a questionable arrest of the contrast at $T_{3} / 4$ vertebral level. Laminectomy was performed (in I966), but no abnormality was seen. A complete cord lesion with a level corresponding T8 segment persisted. This patient reached independence but had recurrent urinary tract infections despite good control of his diabetes mellitus. Pyelography showed moderate hydronephrosis. He has an autonomous bladder with markedly increased capacity, uses a urinal and voids with manual pressure. There have been no fractures, but recurrent skin ulcers pose great problems.

\section{Results of NCV}

NCV was within normal limits in the upper limbs in all four cases. However $\mathrm{H}$-reflexes and motor NCV were not measurable in the lower limbs. On the other 
hand NCV were easily recordable and found to be normal in seven children with spastic traumatic paraplegia.

\section{Results of Myelography}

Representative aspects and corresponding line drawings of myelographs of cases $I$ and 2 are shown in Figs $I$ and 2 (for description see legends). CSF analysis was normal in both cases.

For comparison, in Fig. 3 an air myelograph is shown of a four-year-old girl with a diagnosis of transverse myelitis one year previously. She had persistent flaccid paraplegia, areflexia of her lower limbs and urinary incontinence due to a
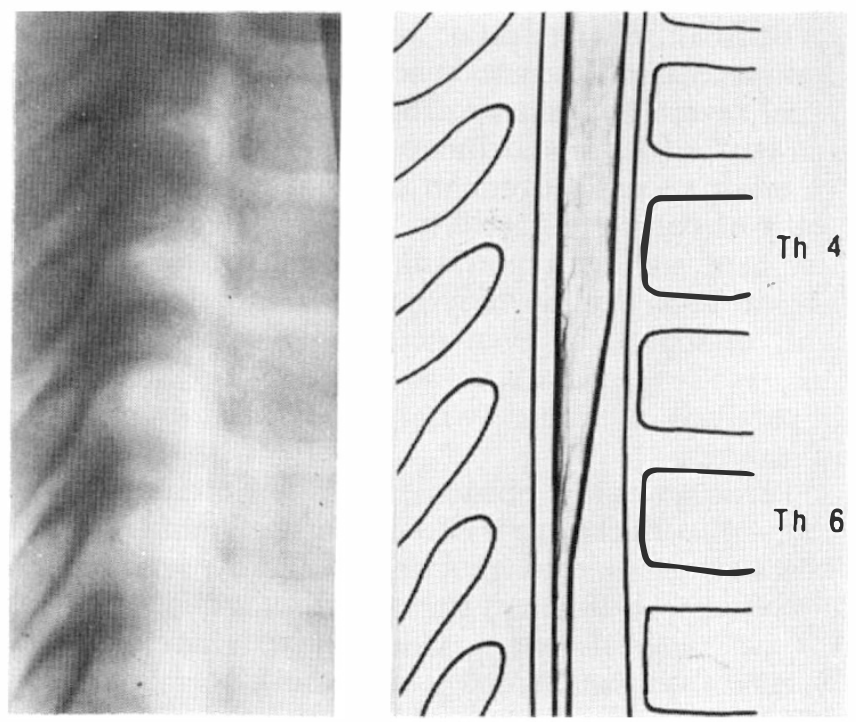

FIG. 3

Air myelography, lateral view. Four-year-old girl with complete lesion corresponding to $\mathrm{T}_{4} / 5$ segment, one year after transverse myelitis. The spinal cord tapers off below $\mathrm{T}_{4}$ vertebra to become string-like at and below T6 vertebra.

complete transverse lesion at $\mathrm{T}_{4} / 5$ segment. Follow-up studies show that her condition has been unchanged in the past 3 years. She has an autonomous bladder.

\section{Discussion}

In the four cases described an additional lower motor neurone lesion resulting in flaccidity and areflexia had to be assumed. This was supported by neurophysiological investigations (i.e. absence of recordable NCV) and in two patients further substantiated by radiological evidence of myelomalacia. In view of the assumption of a lower motor neurone lesion at spinal (anterior horn) level it was interesting to realise that these patients clinically have an autonomous bladder, although unfortunately urodynamic and sphincter electromyographic studies are not available. Despite intensive training these patients did not succeed in emptying their bladder by suprapubic tapping but they void at regular intervals by manual pressure, partly assisted by abdominal pressure. This can be explained by destruction of the spinal bladder centre. We speculate that permanent flaccidity following thoracic cord trauma as a rule coincides with an autonomous bladder, although this 
is not explicitly clear from the literature. From the urological point of view this may be disadvantageous but, on the other hand, it is of benefit to these patients not to be subject to flexor-adductor spasms and clonus of the lower limbs. In our limited experience flaccidity certainly does not impede rehabilitation for ambulation.

Regarding pathogenesis, it is worth emphasising that cases $2-4$ had sustained only comparatively minor trauma to the spine and that a few minutes to about half an hour elapsed before paraplegia was complete. This points to vascular factors being inflicted although the exact mechanism and the pattern of the assumed infarction is open to speculation. In view of the complete transverse lesions it is very unlikely that occlusion of the anterior spinal artery or the arteria radicularis magna of Adamkiewicz had occurred. Haemorrhagic infarction from a pre-existing spinal vascular malformation seems also most improbable as the CSF was clear. General severe hypoxia or drop in perfusion pressure which can be causative in spinal stroke (Silver and Buxton, I966) did not occur in our patients.

In two large adult series (Guttmann \& Frankel, I966; Guttmann \& Walsh, I97I) the frequency of complete flaccidity in thoracic cord trauma can be calculated to be $\mathrm{I} 2$ per cent. Other reports mentioning permanent flaccidity do not state the neurological level nor do they correlate the clinical observations with neurophysiological, urological or even neuroradiological investigations (RiveraDominguez et al., 1978-79; Girard et al., 1978-79). Judging from the scant literature, flaccid paralysis in children with thoracic cord injury is very rare or has not created great interest.

In larger paediatric series this phenomenon is not even mentioned (Meinecke, I972; Hachen, I977-78). Burke (I97I) described two young children with permanent flaccid paralysis following cord injury at $\mathrm{T}_{3}$ and $\mathrm{T}_{4}$ segment. Ahmann et al. (I975) reported two patients in whom spinal cord infarction due to minor trauma was confirmed by pathological study. One case was flaccid in the upper limbs only, while the second case was tetraplegic and areflexic.

Permanent flaccidity and areflexia has occasionally been observed following birth trauma to the spinal cord (Allen, I970; Fontan et al., I964; Jellinger \& Schwingshackl, 1973). In our personal series of Io cases (Bucher et al.) one boy with a level at $\mathrm{T}_{4}$ segment remained flaccid and areflexic and NCV was not measurable in the lower limbs. Some cases with transverse myelitis also result in permanent flaccidity (Ropper \& Poskanzer, I978). Fig. 3 shows the myelogram of a personally examined child diagnosed as having had transverse myelitis one year previously. Extensive spinal cord destruction (myelomalacia), presumably on a vascular basis, seems to be responsible for her permanent flaccidity.

\section{SUMMARY}

From January I960 to March 197925 children with spinal cord injury were admitted to our hospital (Io newborns with birth injury to the spinal cord were excluded). Among I2 patients with complete thoracic lesions four remained permanently flaccid. These four cases who had sustained relatively minor trauma showed marked muscular atrophy of the lower limbs, areflexia, absence of anal and cremasteric reflexes, no response to plantar stimulation and no foot deformities. In contrast to children with spastic traumatic paraplegia, motor nerve conduction velocities and H-reflexes were not measurable in these flaccid patients. Myelography was performed in two, this showing myelomalacia below the level of injury. All four patients had clinically an autonomous bladder and voided by gentle 
manual pressure. The clinical, neurophysiological and radiological findings are consistent with a lower motor neurone lesion below the level of cord injury, resulting presumably from an extensive longitudinal cord lesion on a vascular basis. Judging from Guttmann's experience, flaccid paraplegia occurs in about 12 per cent of adults with complete thoracic cord lesions. The literature is too scant to give an estimate of this complication in children with traumatic paraplegia.

\section{RÉSUMÉ}

Vingt-cinq enfants avec une paraplégie traumatique furent hospitalisés dans notre clinique entre le début de l'année I960 et mars I979 (non compris Io nouveau-nés avec une lésion de la moelle épinière due a un traumatisme lors de l'acouchement). Quatre patients parmi les I 2 qui avaient une lésion transverse complète de la moelle épinière au niveau thoracique restèrent complètement paralysés avec une paralysie flasque. Ces quatre patients, qui avaient souffert par ailleurs d'un traumatisme relativement insignifiant, présentèrent les signes suivants: atrophie musculaire nette des jambes, aréflexie tendineuse, inhibition du réflexe anal et crémasterien. Aucun ne developpa une déformation des pieds. Le réflexe $\mathrm{H}$ et la vitesse de conduction nerveuse mesurés aux jambes n'étaient pas enregistrables contrairement aux enfants atteints d'une paralysie spastique. Une myélographie fut faite chez deux patients et montra une myélomalacie en dessous du niveau de la lésion transverse. Les quatre patients présentèrent cliniquement une vessie autonome qui pouvait être vidée manuellement. Les éxamens cliniques, neurophysiologiques et radiologiques parlent en faveur d'une dégénérescence du deuxième motoneurone situé en dessous de la lésion transverse due probablement è des troubles vasculaires. Dans des séries étendues de Guttmann se référant aux adultes I 2 pourcents des lésions transverses complètes de la moelle épinière thoracique evoluent vers une paraplégie flasque. Il n'existe pas dans la littérature des résultats analogues chez l'enfant.

\section{ZUSAMMENFASSUNG}

Von Januar 1960 bis März 1979 wurden in unserer Klinik 25 Kinder mit traumatischer Paraplegie hospitalisiert (IO Neugeborene mit geburtstraumatischen Rückenmarksverletzungen nicht eingeschloßen). Von I2 Patienten mit vollständiger thorakaler Läsion blieben 4 völlig schlaff. Klinisch waren diese Fälle, die ein relativ geringfügiges Trauma erlitten hatten, gekennzeichnet durch deutliche Muskelatrophie an den Beinen, Areflexie sowie Fehlen von Anal- und Cremasterreflex. Es bestanden keine Fußdeformitäten. Im Gegensatz zu Kindern mit spastischen traumatischen Paraplegien konnten bei den schlaffen Patienten an den Beinen keine Nervenleitgeschwindigkeiten und kein H-Reflex registriert werden. Die bei 2 Kindern durchgeführte Myelographie ergab eine Myelomalazie unterhalb des Niveaus der Querschnittsläsion. Klinisch besteht bei allen 4 Patienten eine autonome Blase, die durch vorsichtige manuelle Expression entleert wird. Klinische, neurophysiologische und neuroradiologische Befunde sprechen für einen Ausfall des unteren Motoneurons unterhalb der Querschnittsläsion, vermutlich auf vaskulärer Grundlage. In Guttmann's umfangreichen Serien sind I 2 Prozent der vollständigen thorakalen Querschnittslähmungen Erwachsener in eine schlaffe Paraplegie übergegangen. Entsprechende Zahlen sind für das Kindesalter nicht verfügbar.

\section{REFERENCES}

Ahmann, P. A., Smith, S. A., Schwartz, J. F. \& Clark, D. B. (1975). Spinal cord infarction due to minor trauma in children. Neurology, 25, 30I-307.

Allen, J. P. (1970). Birth injury to the spinal cord. Northwest Medicine, 69, 323-326.

Bucher, H. U., Boltshauser, E., Friderich, H. \& Isler, W. (1979). Birth injury to the spinal cord. Helv. Paed. Acta, 34, 517-527.

Bucher, H. U., Boltshauser, E., Friderich, H. \& Isler, W. (I980). Traumatische Querschnittslahmungen im kindesalter. Schweiz. Med. Wschr., I10, 33I-337.

Burke, D. C. (I97I). Spinal cord trauma in children. Paraplegia, 9, I-I 4.

Fontan, A., Verger, P. \& Battin, J. J. (1964). Le traumatisme médullaire. Ann. Pédiat., 40, 23 I-239. 
Girard, R., Minaire, P., Casteran, J. P., Berard, E. \& Eysette, M. (1978-79). Anal and urethral sphincter electromyography in spinal cord injured patients. Paraplegia, I6, 244-247.

GutTMANN, L. \& Frankel, H. (1966). The value of intermittent catheterisation in the early management of traumatic paraplegia and tetraplegia. Paraplegia, 4, 63-84.

Guttmann, L. \& Walsh, J. J. (I97I). Prostigmin assessment test of fertility in spinal man. Paraplegia, 9, 39-5I.

Guttmann, L. (1973). Spinal cord injuries. Comprehensive management and research. Blackwell Scientific Publications, Oxford.

HACHEN, H. J. (1977-78). Spinal cord injury in children and adolescents: diagnostic pitfalls and therapeutic considerations in the acute stage. Paraplegia, 15, 55-64.

JeLlingeR, K. \& SCHWINGSHACKL, A. (I973). Birth injury of the spinal cord. Report of two necropsy cases with several weeks survival. Neuropädiatrie, 4, I I I-I23.

MEINECKE, F. W. (1972). Querschnittslähmungen im Kindesalter nach Unfällen. Suppl. to $Z$. Kinderchir., II, 633-654.

Rivera-Dominguez, M., Dibenedetto, M., Frisbie, J. H. \& Rossier, A. B. (I978-79). Pes cavus and claw toes deformity in patients with spinal cord injury and multiple sclerosis. Paraplegia, 16, 375-382.

Ropper, A. H. \& PoskanZER, D. C. (I978). The prognosis of acute and subacute transverse myelopathy based on early signs and symptoms. Ann. Neurol., 4, 5I-59.

Silver, J. R. \& Buxton, P. H. (I974). Spinal stroke. Brain, 97, 539-550. 